\title{
Ethnography of death in Palestine
}

\section{Introduction}

The last five decades have witnessed an increasing concern with mortuary remains as a source of information to infer some aspects of past social systems. Archaeologists and anthropologists recognized that a great variety of information is potentially incorporated in mortuary remains. ${ }^{1-3}$ The processual approach has stressed the significance of the mortuary remains as an area of mutual interest between archaeology and ethnography. ${ }^{4}$ Various attempts have been made to provide correlations between mortuary behavior and social system. ${ }^{1-3,5-11}$ Some scholars have argued against a systematic linking between mortuary remains and the social system, ${ }^{12-14}$ stressing the specific nature of the mortuary practice and the role of ideology. This controversy about the use of funerary remains is due to the fact that its justification rested largely on ethnographic rather than on archaeological grounds. ${ }^{3}$ However, the whole mortuary theory is based on the assumption that social differentiations, weather by age, sex, social position etc., is reflected by mortuary differentiation of the dead. ${ }^{6}$ This correlation does not imply that mortuary practices are merely a passive reflection of social life. ${ }^{14}$ It is also evident that some aspects of mortuary symbolism will not be detected by mortuary analysis and therefore only a minimal level of internal differentiation is expected to be displayed. ${ }^{3,15}$ But there is no doubt that this mortuary analysis provides archaeologists with a valuable tool to interpret the mortuary archaeological remains. However, In 1980s and 1990s the post-processual scholars argued that mortuary practices are not a simple reflection of social systems ${ }^{16}$ New research in the last two decades has focused on mortuary rituals and their role in social memory, identity, gender and location of the burial, with extensive use of ethnographic data. All trends of mortuary analysis However, both processual and post processual approaches recognized the value of ethnographic data in mortuary analysis.

In Palestine, mortuary remains has been traditionally subject to chronological and typological studies by culture historians. ${ }^{17-25}$ Only in late 1970's and 1980's were mortuary remains subjected to systematic mortuary analysis. ${ }^{9,26,27}$ The first attempt to apply mortuary analysis on a Palestinian burial ground was done by Wright ${ }^{9}$ who studies the early Natufian mortuary differentiation at Mugharet el -Wad. Mortuary analysis was applied in the study of the Chalcolithic mortuary sites at Shiqmim. ${ }^{26}$ Shay $^{27}$ examined the mortuary differentiation in the EB-MB burials at Jericho. Another approach to the problem is represented by Dever ${ }^{28}$ who recognize the importance of the ethnoarchaeological method but was not able to go beyond the traditional cultural paradigms "continuity and discontinuity" in his discussion of MB I burials in Palestine.

The following ethnographic account is based on secondary ethnographic sources. ${ }^{29-38}$ Most of these ethnographic observations were collected early in this century, when the Palestinian society was fully intact, before the massive Zionist immigration to Palestine and the radical demographic change in 1948. Systematic ethnographic investigation was carried out by the Swedish anthropologist Hilma Granqvist, who wrote her trilogy of the three major events in human life (Birth and childhood, marriage, and death) in the village of Artas, south of Bethlehem. This monumental work represents without doubt

\author{
Volume 3 Issue I - 2018
}

\author{
Hamdan Taha \\ Researcher, Former Director of the Palestinian, Department of \\ Archaeology and Cultural Heritage, Palestine
}

Correspondence: Hamdan Taha, Researcher, Former Director of the Palestinian Department of Archaeology and Cultural Heritage,Palestine,Email htaha99@yahoo.com

Received: June 12, 2017 | Published: February 23, 2018

the corner stone of all ethnographic studies in Palestine. Her later work $^{30}$ is a vivid account of the mortuary variability in the village of Artas. Although the mortuary practices at Artas conform in broad lines with the Muslim burial rituals, their local, distinctive character is evident. The ethnographic mortuary data reflects the main socioreligious structure of Palestinian society as well as, the rural-urban social distinctions. It is important to note that the religious mortuary behavior stemming from the religious Islamic sharia is out of the scope of this study.

Simple ethnographic observations on peasant and nomadic Palestinian society have been used by culture historians and biblical scholars to explain past remains. Following these observations, prehistoric behavior patterns are described, then an analogous ethnographic behavior is searched in contrast to the ethnographic analogy characteristic to a systematic ethno-archaeological approach, where an ethnographic model is constructed and then tested against archaeological mortuary remains. ${ }^{39}$ One example of the history of culture kind of ethnographic analogy in Palestinian archaeological research is the comparison between Neolithic social groups ${ }^{40}$ and the modern Bedouin groups of Palestine.

Only in the last decades have ethnographic data been used systematically in Palestine and the Near East to investigate demographic structure, subsistence, technology, residence pattern and mortuary practice of prehistoric groups, ${ }^{41}$ But rarely in interpreting mortuary differentiations in Palestine. ${ }^{42,43}$ This is related probably to the apparent egalitarian nature of the Muslim mortuary rituals. But the mortuary practices are not only a reflection of an egalitarian ideology. This may be indicated by the practice of cremation in England, ${ }^{44}$ which is in direct opposition to the Christian doctrine of the resurrection of the body.

William Dever ${ }^{28}$ used ethnographic data to explain the substance pattern associated with Middle Bronze Age I mortuary practices. Levy and Alon ${ }^{26}$ compared Chalcolithic mortuary remains from Shiqmim with Hawaiian data to further their assumption of the existence of a chiefdom order. They propose using ethnographic data from Indonesia, Borneo and Madagascar, to prove that secondary burial practice is associated with sedentary societies ${ }^{26}$ and not with nomadic ones as suggested by the history of culture approach. ${ }^{45,46}$ The ethnographic model proposed here serves to widen our perspective for explaining 
mortuary differentiation of the past. One purpose of this model is to demonstrate the potential of the ethnographic data in Palestine and how they may be used by archeologists to infer the past social system. It may serve as an independent variable to control the interpretation of archaeological data. Ethnographic data provides archaeologists with a unique source for examining the role of ideology in burial practices. Mortuary variability in Palestine is reflected with respect to location, burial structure, age and sex of the deceased, furniture facilities, posture and orientation of the deceased.

\section{Location}

Traditional cemeteries in Palestine are found either in the center or in a close proximity to the dwelling areas, expect on the west side to avoid the west wind. ${ }^{47,48}$ These cemeteries which form an organic part of the modern Palestinian village or city were originally extramural. Change in this spatial relationship is a result of the modern expansion of these settlements. Anyway, location is a central theme of the Palestinian mortuary practice. There is nothing severe as death far away from home. The devotion to the place is expressed in several local burial songs. ${ }^{30}$ People avoid being buried in isolated places and they prefer to be buried among their relatives and friends, ${ }^{33}$ with the exception for some religious places..$^{30}$ Another pattern is represented by some mobile groups. The gipsies (Nawar) in Palestine bury their dead in the cemetery nearest to the place where they are temporarily living. ${ }^{36}$ A similar practice was observed among the nomads of south Persia, where the dead are carried to a close village cemetery and never buried out in the hills.

In Palestine, a spatial relationship between cemeteries and saints (welis) is observed by T Canaan ${ }^{49}$ where he found that $30 \%$ of all Muslim cemeteries were grouped around a weli.$^{49}$ The close relatives of the holy were also buried in association with some sanctuaries. ${ }^{49}$ The tombs of holy men, high ranked religious persons, occurred inside the village among the houses, as well as outside the village in the fields or in a cemetery ${ }^{49}$ The Jews of Palestine had no common burial place. ${ }^{48}$ The cemeteries of the Bedouins in the Negev are located frequently near a well. The deceased is taken there where he is washed and buried. ${ }^{33}$ Ancient ruins adjacent to water are the most preferable burial place for the Bedouins in Transjordan. ${ }^{37}$ Musil pointed out that ancient ruins are preferred because stones needed for the burial are available and because of the difficulties in cutting in hard and rocky surface with bad tools. ${ }^{37}$ Canaan describes the practice among monadic and semi-nomadic groups in Palestine who take their high ranked dead a great stance to be buried near a saint's tomb. ${ }^{49}$ This practice is also reported among the monads of south Persia, where they take their prominent men to be buried near a shrine. ${ }^{50}$ Differential treatment of infants and children is indicated by different locations of burials. Some Palestinian peasants bury their children in the immediate neighborhood of a sanctuary, ${ }^{31}$ or in a separate cemetery as in the case of infant graves at Bethlehem, ${ }^{30}$ as in the case of children burial ground close to Rachel Tomb, north of Bethlehem. This spatial pattern is observed at Hasan Abad in Iran, where a separate cemetery for babies is found. ${ }^{51}$ Among the peasants in Egypt still-born infants and miscarriages are buried in the corners of the rooms of their houses. ${ }^{52}$

\section{Pre-interment treatment of the dead}

Differentiation in the pre-interment treatment of the dead related to ideological differences are evident: the Muslims are oriented toward the (southeast) - toward Mecca ${ }^{29,30,36,38}$ and Samaritan dead are turned toward Mount Gerizim. ${ }^{35}$ A differential treatment in the Samaritan mortuary practice may be indicated by a light lit around the dead of high special status from the moment of death until his departure, ${ }^{35}$ the ankles are bound together and the hands placed upon the breast. ${ }^{38}$ Two burials were reported from the med vial cemetery at Tell el-Hesi which differed from the common pattern for face direction which may reflect ignorance of the burial rites.

\section{Washing and clothing}

The corpse is washed with soap and warm water (camphor is added sometimes) in two processes, first by those nearest to the dead, and then the ritual washing by a professional washer. ${ }^{29,33}$ Little children are washed normally by the midwife. ${ }^{30}$ Adult males were washed normally at home, but in exceptional cases at the door of the mosque, and women and children are washed as rule at home. ${ }^{30} \mathrm{As}$ a rule women are washed by women and men are washed by men. ${ }^{33}$ Only in certain cases are the dead washed by the opposite $\operatorname{sex}^{30}$ and in special cases a woman must be washed through her clothes or not washed at all if no close relatives are present. ${ }^{38,53}$ Among Christians in Palestine dead is not washed ritually. ${ }^{30}$

The corpse is wrapped in a shroud ${ }^{30,36}$ or buried in ordinary clothes, in white and green color but not red. ${ }^{53}$ Among the Sukhur tribe in Jordan the dead are buried in their ordinary clothes. ${ }^{37}$ Different clothes were used for the two sexes at the village of Artas. ${ }^{30}$ The dead are clothed in linen garments (certain colors such as red, blue, or purple are forbidden) by the Samaritans ${ }^{35}$ Among the Christians the deceased is clothed in his best clothes and flowers are placed in his coffin. ${ }^{33}$ No coffins were used by the Muslims, ${ }^{30,33}$ and many Christians, especially in villages, used no coffins. ${ }^{33}$ Differentiations may be indicated by the use of an additional shroud..$^{33}$ In Egypt, a piece of cotton is used for the lower class and muslin and cotton of thicker texture for the upper class. ${ }^{38}$ The women who had married two times are provided with two shrouds. ${ }^{33}$ All the openings of the body are closed, except the ears, so that the dead should be able to hear the word of the ceremony ${ }^{30}$ But it seems that only the gipsies (Nawar) are buried without shrouds, ${ }^{30}$ as well as extremely poor people or in times of famine and epidemics.

\section{Ceremonial prayer and the time of the burial}

The male dead are carried to the mosque for a special prayer before the final interment, but prayers are always said over a woman at home. ${ }^{30}$ Generally, the custom is to bury the dead as soon as the grave is finished, for burial is regarded as an urgent matter. ${ }^{30}$ If the death occurred in the morning the burial takes place on the same day (Lane 1871:252) and never postponed by more than one day by the Samaritans. ${ }^{35}$

\section{Grave}

Stone-cist burials consisting of two rows of large stones, and covered with flat stone slabs were common in the village of Artas. ${ }^{36}$ They may also be cut into the rock or a natural cave was used. ${ }^{30}$ Such features were used indiscriminately for women and men. ${ }^{33}$ The type and structure of the grave is determined inter alia by the physiological nature of the area. Granqvist points out that in a mountain village like Artas natural caves were used often as family graves. The opening was blocked with a large stone which served as a door. ${ }^{30}$ In the built family graves (Fusqiye) the bones of the previous dead were pushed aside 
to make room for the most recent dead. ${ }^{30}$ Only a few single burials were added. At Tell el-Hesi the graves of the two earlier cemeteries, containing adult burials, are shallow, often unlined, but stone-lined graves have also been found.

Most of the graves are capped with four or five flat stones. ${ }^{54}$ These graves differ from the children burials of the most recent phase, found usually in uncapped and unlined graves, ${ }^{54}$ indicating a low level of energy expenditure, ${ }^{54}$ a practice reported by Musil in Transjordan. ${ }^{37}$ The opening of the grave is closed with a large stone and mortar. ${ }^{30,37}$ Structural features symbolizing the social position of the deceased occurred in the Muslim burials. A superstructure is erected over the graves of the persons of rank or wealth ${ }^{37}$ although it is not preferred according to the Islamic burial rites. ${ }^{33}$ But even poor and rich shrines of the holy men were adorned in this way. ${ }^{49}$ Stone huts were used as funeral monuments for Bedouin sheiks. ${ }^{55}$ Differentiations in the Aliabad cemetery in Iran are indicated by different grave markers, according to the rank of the deceased. Cement and hand curved stone markers marked individuals with higher economic rank than the majority marked with cobble stone. ${ }^{51}$

A striking feature is represented by the practice of burying infants in pottery jars attested until very recent times in several sites south of Palestine. Archaeological and ethnographic evidence of this practice comes from Tell el-Hesi, Tell Mubarak, Tell et-Teyyur, ${ }^{56}$ Bir es-Seba' and Tell esh-Sharia, ${ }^{57}$ Gaza and Khan Yunis. At Tell el-Hesi a jar burial of an infant was reported in the 19070-71 season. ${ }^{58,59}$ In the 1979 and 1981 seasons four jar burials containing the skeletal remains of three premature and one full-term infant were excavated in Field VI and $\mathrm{V},{ }^{58,59}$ the burial jars used at the Tell el-Hesi cemetery are typical Gaza household pottery, indicating that it was not made intentionally for mortuary purposes. At Tell Mubarak four jar burials, similar to Gaza water jars were found in the Muslim cemetery dated to the nineteenth century onwards Figure $23 .{ }^{57}$ The cemetery belongs to the nearby Palestinian village Jisr ez-Zarqa. Three of the jars had been broken at the base or mouth in order to enter the corpse. An infant and two fetuses were identified in the four jars, including an infant in jar, $\mathrm{T}-13$ and two fetuses of eight and nine months in jar,T-12 and T-13. ${ }^{57}$ The jar burial, T-12 had no grave goods. It is evident that simple cist burials were the normal burial practice at Tell Mubarak and infant burials in jars represent most likely a differential treatment, since two out of three were fetuses. Ethnographic evidence of infant and children burials in jars is known in the Gaza region. Children burials in jars were found in association with Esh Sheikh Nuran sanctuary, near Khan Yunis, as reported by Canaan. ${ }^{49}$

\section{Posture and orientation of the dead}

A normal posture is to lay the dead on his right side, with the right hand under the head and with the face toward the south (toward Mecca) and the head westwards. ${ }^{30,38}$ In the Christian practice, the deceased is laid on his back, with the face turned toward the east. ${ }^{33}$ In the post-medieval cemetery at Tell el-Hesi single burials were found in an extended posture, lying on their backs with the right hand at the side and the left one at the pelvis. ${ }^{54}$ Only in a few cases the dead was laid in a flecked posture. ${ }^{54}$

\section{After the burials of the dead}

There are a series of meals and ceremonies which take place after the burial of the dead. In the evening at the day of the burial the close male relatives are invited to a meal called "supper of the deceased" by one of the relatives of the departed..$^{30,33,36}$ Social differentiation in funeral meal and associated ceremonies were observed by Lane in Egypt. ${ }^{38}$ This meal is held for both adult males and females, boys and girls of two or three years or over. ${ }^{30} \mathrm{~A}$ second meal is held for the deceased males and females from the age of five years and upward. ${ }^{30}$ Two other meals followed on the morning of the first day after the burial. ${ }^{30}$ Musil reports that funerary meals in Transjordan occur after the death of a male but not of a female. ${ }^{37}$ The dead are visited on the first three days after and on the first three Thursdays after the burial, on the fortieth day, after six months, one year and on the two Muslim religious feasts.

In the first day after the death the women gather early in the morning and go to the grave, where they wail about one hour. This is repeated until the following Thursday. ${ }^{36}$ These visits take place early in the morning which is related to the belief that the souls of the dead are found over the graves at this moment. ${ }^{32}$ But in Nablus the dead were visited on Thursday afternoon ${ }^{33}$ On the first three Thursdays after the burial, food is made and eaten at the cemetery. ${ }^{33,34,36}$ Only in case of premature death as in the case of the murdered man does this visit take place on the first Wednesday. ${ }^{30}$ On the first three Thursdays food is prepared by the relatives and served either on the grave or at home. ${ }^{30}$

\section{Mourning and wailing}

Although wailing is forbidden according to Islamic burial rites, it is practiced in Palestine. Wailing is generally the job of women, especially the close relatives of the dead. ${ }^{30,33}$ Men never join in wailing ceremonies. ${ }^{36}$ In Palestine there is no ethnographic evidence of the practice of paid wailing ${ }^{30}$ done by public wailing-women practiced in some parts of Egypt. ${ }^{38}$ But it said metaphorically that "everything is debt, including the eye tears".

Canaan mentioned that in the past, professional wailing-women were hired. ${ }^{33}$ In any case, wailing is not done by the female relatives of the deceased only, but rather women from the village and from distant places come and take part in mourning. ${ }^{30}$ Gaster points out that the degree of mourning among the Samaritans is determined by the age and status of the deceased as well as by the degree of kinship. ${ }^{35}$ At Artas women go to the grave of an adult but not to the grave of a child. ${ }^{30,37}$

\section{Unnatural death}

Mortuary differentiations are observed in the case of unnatural death such as martyrs, suicide, murder etc. Martyrs were buried in their clothes without being washed. ${ }^{33,53}$ In the case of suicide, the deceased receives no formal treatment among Muslims, he is neither washed and nor taken to the mosque. ${ }^{33,53}$ This is also the case among the Samaritans and the Jews, and the deceased is buried by the close relatives. ${ }^{35}$ A man who committed suicide from Bethlehem region was buried with his relatives. ${ }^{30}$ Among the Sukher tribe in Jordan, only the close relatives of a murdered man are allowed to take him to the grave and to bury him. ${ }^{37}$ In the case of a murdered man the grave is visited on the first Wednesday after the burial and not on the first Thursday as normal. ${ }^{30}$ The corpse is not washed in the cases where infection is feared, and only water is poured over it. ${ }^{53}$ Differential 
treatment symbolizing unnatural death at Tell el-Hesi may be reflected in the burial of an adult female, with her severed head resting on her abdomen, ${ }^{54}$ an evidence of the practice of decapitation as a punishment for adultery in the traditional Palestinian peasant society. ${ }^{54}$

\section{Burial clusters and social structure of the population}

The social structure is roughly reflected in the traditional Palestinian burial ground. Burial clusters reflect to some extent the existing social structure of the population. This relation is not as clear in other ethnographic cases. ${ }^{14}$ Relatives are buried in the common graves and every clan has its own burial ground..$^{30}$ The family and the clan are responsible for the burial of a kin. Death and burial serve to reaffirm family and kinship relations and to strengthen the inner solidarity of the clan. ${ }^{30}$ There is evidence that members of different clans were buried in one common tomb. ${ }^{30}$ In Mosul in Iraq each family had its own burial ground inside the city. ${ }^{60}$ Three clusters of burials were reported in the cemetery of Aliabad in Iran, one used for children, a second one for adults and a third abandoned section. ${ }^{51}$

At Artas the post marital residence is of course patrilocal where a female comes to live with her husband with his male lineage. A married woman is buried by her patrilineal Kinsmen. In a common grave at Artas women of the same family or clan either born in the same village or in other villages were buried in the same grave..$^{30}$ It is evident that the outsider women were buried in the burials of the husband's family or clan, although when a married woman dies she again becomes a member of her father's house. She is carried by her brothers to the grave as is the unmarried woman. Her husband cannot burry her. ${ }^{30}$ Differentiations at Artas may be indicated by clan members who are not buried in the clan burial ground, because they wished to be buried elsewhere ${ }^{30}$ or deprived of being buried in the clan's burial as in the case of sinned women..$^{30}$ Granqvist reports that some Artas women were buried at Rahel's tomb, in Bethlehem. ${ }^{30}$ Mortuary differentiations between city and village are evident with respect to pre-interment treatment of the dead.

\section{Sex and age distinctions}

Sex distinction is reflected in the traditional Palestinian burials. In the family graves, the two sexes were buried in two chambers or a partition is built to separate the two sexes in a communal grave..$^{30,38,53}$ Each chamber has a separate entrance. ${ }^{33}$ The only exception is in the case of death after birth, where the mother and the infant may be buried together. ${ }^{33}$ In the post-Medieval cemetery at Tell el-Hesi, a grave containing the burials of a young woman and an older man was found. The two skeletons lay on their right side, their heads separated by a stone divider and the lower part of their bodies in contact. ${ }^{54} \mathrm{~A}$ special treatment is accorded to the unmarried girls at Artas. They are painted and gilded, their eyes are blackened. Henna (Losowina alba) is dusted over their bodies and they are sprinkled with perfume. A piece of soap and a comb are put in the grave.$^{30}$ These girls are adorned with gold according to a burial song from Artas. ${ }^{30}$ Among the Sukher tribe in Jordan,, women are glided and provided with their ornaments as in the case of a weddings. ${ }^{37}$ Differential treatment of juvenile and adult women at Aliabad in Iran are indicated by the occurrence of burial markers that are both most costly and numerically less common. ${ }^{51}$

At Artas children's funerals are generally much simpler than those of adults. In Bethlehem adults are buried in Rahel's tomb, while infants and children were buried in the children's cemetery near Rahel's tomb. ${ }^{30}$ Not all ceremonies are performed in the case of children in Egypt. ${ }^{38}$ Children are not treated formally as the adults among the Samaritans, they are merely washed and buried in new garment and only men go to the funeral of a child. ${ }^{35}$ The male child which dies uncircumcised has to be buried in exactly the same manner as any small child, as the Samaritans do not follow the Muslim custom of post-mortem circumcision. ${ }^{35}$ Comparative ethnographic evidence is reported from Iran. At Aliabad many children's graves are left completely unmarked ${ }^{51}$ and at Hasan Abad babies are buried in a special cemetery. ${ }^{51,61}$

If a child and an adult die on the same day, the dead child is placed on the knees of the adult. Granqvist ${ }^{30}$ reports a case at el -Khadar near Bethlehem where a child was placed in the arms of an adult, and since infants and little children are free from sin, they give protection to the adults. In the Palestinian peasant society children begin relatively early to help in the family economy, boys help to herd the sheep and to preform simple agricultural activities, while little girls are set to work even earlier than boys and have to assist in the household work or in carrying water. ${ }^{31}$ The boys of 12 years of age were regarded as mature in certain cases. ${ }^{30}$ No special treatment is accorded to the people of very advanced age at Artas. ${ }^{30}$

\section{Social stratifiction}

At Artas, mortuary differentiation varies with the social status of the deceased despite the egalitarian nature of the dominant ideology. The funeral of a sheik, a clan head, or a high ranking religious person differs in many respects from other individuals. The main indices are the structure of the grave, its spatial association to saints' shrines, number of participants in the burial, number of visitors from other villages and the luxury of the death meals.

\section{Funerary offering}

Only a few funerary goods are normally found in the Muslim Burial, ${ }^{33}$ consequently it could not be used as a reliable indicator of wealth. At Tell el-Hesi simple personal ornaments, such as beads, rings, bracelets, anklets and pendants were found in association with the Muslim burials. ${ }^{54,62}$ One burial was associated with a water jar, ${ }^{54}$ another burial of an infant had a pierced coin attached to the right mandible. This practice was reported by Granqvis ${ }^{30}$ at the village of Artas. A flint (to light the fire) and coffee utensils were reported to be placed in the grave of a man from Artas. ${ }^{30}$ Canaan points to a similar custom among the Bedouins of the Negev. Concave bowls were frequently left on the upper stone slabs, and they were filled with water at each visit. Coffee utensils were laid on some graves, symbolizing the hospitality of the deceased. ${ }^{33}$ The Bedouins of Sinai leave the clothes of the deceased on the grave until they fall into pieces or are taken by poor people. ${ }^{33}$ This practice is reported also among the Bedouin in Transjordan. ${ }^{37}$ The Azazema and Zullam tribes placed a jug filled with water against the dead of the dead. ${ }^{37}$ The Hewatat tribe provided the men with flour and the women with a paint stick $(k o h l) .{ }^{37}$

Personal ornaments such as beads were reported in Bedouin's tombs in Negev and Sinai. A coin was attached to the hood over the forehead or nose of the Qais woman. ${ }^{30}$ Dried Henna is strewn over and beneath the dead. ${ }^{30}$ Canaan reports that a layer of henna is laid under the dead and the thickness of this layer correlates to the social 
status of the deceased. ${ }^{33}$ A maiden girl is painted and glided etc. and a piece of soap and a comb are put in the grave.$^{30}$ Generally, funerary offerings are not placed in the grave. At Artas gifts consisting of personal ornament were collected in a sack before the final interment. After a special ceremony at the grave they were returned to their real owners and instead some money is scattered on the grave for the soul of the deceased..$^{30}$ The preacher who did the ceremony is paid..$^{30}$ This practice which has only a symbolic character may be an echo of a preIslamic burial practice.

\section{Infant mortality}

Early in this century, a high infant mortality in Palestine was indicated in ethnographic sources. An excellent ethnographic account of diseases which affect the children in Palestinian superstitions was given by $\mathrm{T}$ Canaan ${ }^{31}$ a physician from Jerusalem. In addition to the dominant fatalistic view, he points to the demons, especially elQarina and Umm es-Subian ${ }^{32}$ whose duty is to injure infants, to attack pregnant women and to cause miscarriage. ${ }^{31}$ Regional and social variability in infant mortality was indicated by high rates of infant mortality among the peasants and the lower class of city inhabitants. In a sample (from Dr. Canaan's private statistics) of 2185 pregnancies $20 \%$ ended in abortion and still birth. Of the remaining 1740 children born alive $44.7 \%$ died within a brief time, ${ }^{31}$ indicating high rates of infant mortality at the beginning of the $20^{\text {th }}$ century in Palestine. Early feeding of children and the irregularity of giving food is a major cause of most of the gastric and intestinal troubles which often end in death, ${ }^{31}$ especially among the lower class. The most recent phase of the post-Medieval cemetery at Tell el-Hesi consists entirely of infants' burials, between eighteen months and three years old, which may represent the victims of a plague..$^{54}$

\section{Conclusion}

Although some specific features of the traditional Palestinian mortuary practice are not clear in this ethnographic account, it shows clearly the mortuary treatment varies with religious affiliations, social rank, age and sex of the deceased. Differentiation in the mortuary treatment of the Muslims, Christians, Samaritans and Jews is observed. Despite the egalitarian nature of the Muslim burial rites, social differentiations based on socio-economic position are evident with respect to the grave structure, presence or absence of a superstructure over the grave, the length of mourning periods, death meals, the number and the distance travelled by the people who come from other villages to attend the burial. Age, sex, wealth and rank of the deceased are the main determinants of the mortuary variability at Artas. Infants and children up to the age of 10 years are treated different than adults. Sex distinction is evident by differential treatment accorded to the two sexes and by the spatial distinction of the burials of the two sexes. Sex distinction is indicated by the special treatment of young unmarried women, decorated and glided, and provided with a comb and a piece of soap. As a rule no grave goods are included in the burials, but in certain cases some grave goods were found. Differential treatment is accorded to individuals of unnatural death, as in the case martyrs, murdered people, those who commit suicide and women who have sinned.

\section{Acknowledgements}

None.

\section{Conflict of interest}

Author declares that there is no conflict of interest.

\section{References}

1. Tainter J. Social Inference and mortuary practices: an experiment in numerical classification. WA 1975;7:1-15.

2. Alekshin VA. Burial Customs as an Archeological Source. Current Anthropology. 1983;24(2):137-49.

3. O'Shea J. Mortuary Variability: An Archeological Investigation. Orlando: Academic Press; 1984

4. Chapman RW. Burial Practices: An Area of Mutual Interest. In: Spriggs M, editor. Archeology and Anthropology. Areas of Mutual Interest. BAR Supplementary Series; 1977:19.

5. Saxe A. Social dimensions of mortuary practices. Ph.D dissertation. Univresity of Michigan Microfilm, Ann Arbor; 1970.

6. Binford LR. Mortuary Practices: Their Study and their Potential. In: Binford LR, editor. Archeological Perspectives, USA: Seminar Press; 1972:208-239.

7. James BA. Mortuary Practices: Their Study and Their Potential. Approaches to the Social Dimensions of Mortuary Practices. In: James BA, editor. Washington DC: Society for American Archaeology; 1971:92-112.

8. Tainter J. Mortuary practices and the study of prehistoric social systems. In: Schiffer MB, editor. Advances in Archaeological Method. Vol. I, New York: 1978.

9. Wright GA. Social Differentaion in the Early Natufian. In: Redman CL, Longhorne W, editor. Social Archaeology beyond Subsistence and Dating. New York: 1978.

10. Chapman RI, Kinnes, Randsborg K. The Archeology of the Death. Cambridge; 1981.

11. Harrold FB. A Comparative Analysis of Euroasian Palaeolithic Burials. World Archaeology. 1980;12:195-211.

12. Kroeber AL. Disposal of the Dead. American Anthropologist. 1927;29:308-315

13. Ucko P. Ethnography and archeological intrepretaion of funerary remains. World Archaeology. 1969;11:37-58.

14. Hodder I. An Introduction to Anthropology for archeologists. The Present Past. London; 1982.

15. Rakita GFM, Buikstra JE. "Introduction.” In: Rakita GFM, Buikstra JE, Beck LA, et al. editors. Interacting with the Dead: Perspectives on Mortuary Archaeology for the New Millennium. Gainesville, FL: University Press of Florida; 2005:1-11.

16. Rakita GFM. Mortuary Analysis, In: Varela SL, editor. The SAS Encyclopedia of Archaeological Sciences. Wiley-Blackwel; 2017.

17. Guy PLO, Engberg RM. Megiddo Tombs. Oriental Institute Publication 33. Chicago: University of Chicago Press; 1938.

18. Kenyon KM. Excavations at Jericho I. The Tombs Excavated in 1952 54. The British School of Archaeology in Jerusalem, London; 1960.

19. Kenyon KM. Excavations at Jericho II. The Tombs Excavated in 195558. The British School of Archaeology in Jerusalem, London; 1965.

20. Pritchard JB. The Bronze Age Cemetery at Gibeon. Philadelphia; 1963.

21. Callaway JA. Burials in Ancient Palestine: From the Stone Age to Abraham. Biblical Arcaheologist. 1963:26(3):74. 
22. Myers EM. Secondary Burials in Palestine. Biblical Archaeologist 1970;33:1-28.

23. Stiebing WH. Burial practices in Palestine during the Bronze Age. Ph.D. Michigan, Univesrsity of Pennsylvania; Univesrity Microfilms: 1970.

24. Ambercrombie J. Palestinian Burial Practices from 1200 to 600 B.C. USA: University of Pennsylvania; 1979.

25. Ribar JW. Death Cult Practices in Ancient Palestine. Ph.D. University Microfilms, Michigan: Ann Arbor; 1980.

26. Levy TE, Alon D. The Chalcolithic Mortuary Site near Mezad Aluf, Northern Negev Desert: A Preliminary Study. BASOR 1982;248:37-59.

27. Shay T. Burial Customs at Jericho in the Intermediate Bronze Age: A Componential Analysis. Tel Aviv 1983:10:20-38.

28. Dever WG. Funerary Practices in EB IV (MB I) Palestine: A Study in Cultural Continuity. In: Marks JH, Good RM, editors. Love and Death: Essays in honor of Marvin Pope. Four Quarter Publication Company; 1987.

29. Granqvist H. Child Problems Among the Arabs. Helsinki; 1950.

30. Granqvist H. Muslim Death and Burial. Arab Customs and Traditions Studied in a Village in Jordan. Helsinki-Helsingfors; 1965.

31. Canaan T. The Child in Palestinian Arab Superstition. Journal of Palestine Oriental Society. 1927;7:159-186.

32. Canaan T. Daemonegalupe im Lande der Bible. Leibzig; 1929.

33. Canaan T. Paleastinsische Sitten und Gebreauche um den Tod. Zeitschrift des Deutschen Palaestian-Vereins. 1959;75:97-115.

34. Dalman G. Arbeit und Sitte in Palaestina I-VII. Darmstadt; 1928-1942.

35. Gaster TH. Rites and Beliefs of the Samaritans Relating to Death and Mourning. Journal of Palestine Oriental Society 1939-40;19:180-212.

36. Baldensperger PJ. Women in the East. PEFQS. 1901;66-90:268-273.

37. Musil A. Arabea Petraea III, Ethnologischer Reisebricht: Wien; 1908.

38. Lane EW. Modern Egyptians. Vol. II, London; 1871.

39. Flannery KV. Culture History v. Cultural Process: Debate in American Archeology. In: Leone MP, editor. Contemporary Archeology. 1972:102-107.

40. Noy T. Six Neolithic Sites, A sample from Different Geographical Zones of Israel. $\mathrm{PhD}$ thesis, Jerusalem; 1975.

41. Watson PJ. The Theory and Practice of Ethnoarchaeology with Special Reference to the Near East. Paleorient. 1980;6:55-64.

42. Taha H. Prehistoric and Early Urban Differentiation in Palestine with special reference to Tell Taannek. Berlin, Free University of Berlin; 1990.

43. Taha H. Praehistorische und bronzezeitliche Bestattungsreste als Informationquelle fur soziale Differenzierungen in Palastina. In:
Nissen HJ, Kuhne H, Bernbeck R, et al. editors. Fluchtpunkt Uruk, Archeologische Einheit aus Methodologischer Vielfalt, Verlag Marie Leidorf, Rahden/Westf.; 1999:257-268.

44. Pearson MP. Mortuary practices, society and ideology: an ethnoarcheological study. In: Hodder I, editor. Sympolic and Structural Archeology. New Directions in Archeology, Cambridge: 1982:99-115.

45. Gilead D. Burial Customs and Dolmen Problem. Palestine Exploration Quarterly 1968;100:16-26.

46. Perrot J, Ladiray D. Tombes a ossuaires de la rgion cotiere Palestinienne. Paris: Moemoires travaux du Centre de recherches prehistoriques francais a Jerusalem; 1980:1.

47. Klein S. Tod und Begreabnis in Paleastina zur Zeit der Tannaiten. Berlin; 1908.

48. Haeusler A. Zur Problematik der Graebersoziologie. Moderne Probleme der Archaeologie. Berlin: Akademie-Verlag; 1975:83-102.

49. Canaan T. Mohammedian Saints and Sanctuaries in Palestine. Journal of Palestine Oriental Society 1924:4:1-84.

50. Barth F. Nomades of South Persia. USA: Universietsforlaget; 1964.

51. Kramer C. Village Ethnoarcheology. Rural Iran Archeological Perspective. New York; 1982.

52. Macalister RAS. The Excavation of Gezer 1902-1905 and 1907-1909, Vol. II. London; 1912.

53. Tritton AS. Muslim Funeral Customs. Bulletin of the School of Oriental Studies. 1937-39;9:653-661

54. Toombs LE. Tell el-Hesi, 1970-71. Palestine Exploration Quarterly. 1974;106:19-31.

55. Rothschid JJ. Antiquities in the Mountains in Judah The Kh. Mazi. Palestine Exploration Quarterly 1956;88:49-56.

56. Ohata K. Tel Zeror II. The Society for Near Eastern Studies in Japan; 1967.

57. Stern E. Excavations at Tel Movorakh 1973-76. Part One: From the Iron Age to the Roman Period. Qedem 9; 1978.

58. Tombs LE. Tell el-Hesi, 1981. Israel Exploration Journal. 1982;32:67-69.

59. Tombs LE. Tell el-Hesi, 1981. Palestine Exploration Quarterly. $1983 ; 115: 25-46$.

60. Rashid F. Ueber die Toetong weiblicher Neugeborner zum Zweck der Vermeinderung der Gebortanzhal in der Samarra-Tell Halaf' Zeit. Mesopotamia. 1980;8:255-258.

61. Watson PJ. LaBlanc SA, Redman CL. Explanations in Archaeology. New York, Columbia University Press: 1971.

62. Doermann RW, Fargo VM. Tell el-Hesi, 1983. Palestine Exploration Quarterly 1985;117:1-24. 